\title{
PENYULUHAN PENGENALAN BAHAYA MEROKOK, MINUMAN KERAS, DAN NARKOBA PADA SISWA TINGKAT SD-SMP KECAMATAN CAMPAKA KABUPATEN PURWAKARTA JAWA BARAT
}

\author{
Eko Siswono ${ }^{1)}$, Dwi Sukanti Lestari $\mathbf{N}^{2)}$ \\ Fakultas Ilmu Sosial Universitas Negeri Jakarta
}

\begin{abstract}
ABSTRAK
Dalam rangka mempersiapkan generasi emas Indonesia Tahun 2045 penting bagi dunia pendidikan untuk melakukan perubahan cara atau pola pikir. Dunia Pendidikan tidak sekedar dimaknai dengan tranfer akademik (keilmuan) saja, tetapi juga dengan dilengkapi dengan karakter. Keseimbangan akademik dan karakter inilah yang penting dipersiapkan sejak sekarang atau sedini mungkin. Hal ini seperti disampaikan oleh Rektor IKIP PGRI Semarang dalam rangka diskusi ilmiah Tanggal 8 April 2013. Dalam kesempatan tersebut Rektor menekakan, perlunya keseimbangan penguasaan ilmu (akademik, keterampilan, dan karakter) merupakan faktor kunci menghasilkan sumberdaya manusia yang kompetitif. Proses pemeblajaran tidak cukup sekedar meningkatkan pengetahuan melalui core subjects melakinkan harus dilengkapi dengan kemampuan kritiskreatif, karakter kuat yang didukung pula dengan kemampuan memanfaatkan teknologi informasi dan komunikasi.

Agar lebih baik generasi mendatang sesuai dengan pernyataan tersebut, maka muthlak bahwa pendidikan karakter sedini mungkin perlu dipersiapkan, mengingat ancaman, hambatan dan gangguan di luar sekolah mengintai setiap saat, seperti bahaya merokok, minuman keras dan bahkan lebih buruk lagi yaitu bahaya masuknya narkoba di kalangan siswa sekolah dasar dan sekolah menengah. Khususnya narkoba hingga kini penyebaran narkoba sudah hampir tak bisa dicegah.

Berdasarkan uraian di atas, maka dianggap perlu memperkenal-kan kepada siswa sekolah dasar dan sekolah menengah pertama sedini mungkin, tentang bahaya merokok, minuman keras dan narkoba. Sejalan dengan program pengabdian pada masyarakat dan dalam rangka berperan-serta untuk mencegah hal-hal negatif di luar sekolah, maka penting dilakukan upaya pencegahan tersebut melalui penyuluhan sehari yang diselenggarakan bulan Juli minggu keempat 2015, selama dua hari tentang :"Bahaya Merokok, Minuman Keras, dan Narkoba pada Siswa Sekolah Dasar Kecamatan Campaka Kabupaten Purwakarta Jawa Barat”
\end{abstract}

Kata Kunci : Pengenalan Bahaya Merokok, Minuman Keras, Dan Narkoba 


\section{P-ISSN : 0216-7484 E-ISSN : 2597-8926 \\ DOI : doi.org/10.21009/sarwahita.121.07}

\section{PENDAHULUAN}

\section{A. Analisis Situasi}

Berdasarkan analisis situasi dan kajian

pustaka, maka dapat diambil kesimpulan sementara bahwa ada beberapa sekolah dasar di Kecamatan Campaka, Kabupaten Purwakarta perlu dilakukan penyuluhan sedini mungkin, mengingat letak geografis dari sebagian besar sekolah dasar di wilayah tersebut terletak dekat dengan jalan raya menuju ke Kota Subang. Dengan letak geografis seperti tersebut di atas, hal-hal yang terkait dengan ancaman, tantangan, hambatan dan gangguan terhadap minuman keras dan bahaya narkoba di kalangan siswa-siswi sekolah dasar di sepanjang jalan tersebut.

Sehubungan dengan pelaksanaan penyuluhan tersebut, maka dapat dirumuskan permasalahan, seperti di bawah ini agar dapat menangkal kekhawatiran - kekhawatiran tersebut. Rumusan yang dimaksud adalah :

1. Bagaimanakah meningkatkan pemahaman tentang kemungkinan ancaman bahaya merokok, minuman keras dan bahaya narkoba di kalangan siswa sekolah dasar di Kecamatan Campaka Kabupaten Purwakarta ?

2. Bagaimanakah menumbuhkan kewaspadaan siswa sekolah dasar mengenai tantangan, hambatan dan gangguan terhadap bahaya merokok, minuman keras dan bahaya narkoba di Kecamatan Campaka Kabupaten Purwakarta?

\section{B. Fenomena Merokok}

Dalam kehidupan sehari-hari seringkali ditemui orang merokok di mana-mana, baik di kantor, pasar ataupun tempat umum lainnya atau bahkan di kalangan rumah tangga sendiri. Kebiasaan merokok dimulai dengan adanya rokok pertama. Umumnya rokok pertama dimulai saat usia remaja. Sejumlah studi menemukan penghisapan rokok pertama dimulai pada usia 11-13 tahun (Smet, 1994). Studi Mirnet (Tuakli dkk, 1990) menemukan, bahwa perilaku merokok diawali oleh rasa ingin tahu dan pengaruh teman sebaya. Smet (1994), bahwa mulai merokok terjadi akibat pengaruh lingkungan sosial.

Modelling (meniru perilaku orang lain) menjadi salah satu determinan dalam memulai perilaku merokok (Sarafino, 1994). Oskamp (1984) menyatakan, bahwa setelah mencoba rokok pertama, seorang individu menjadi ketagihan merokok, dengan alasan-alasan seperti kebiasaan, menurunkan kecemasan, dan mendapatkan penerimaan. Graham (dalam Ogden, 2000) menyatakan bahwa efek positif dari merokok adalah menghasilkan efek mood yang positif dan membantu individu dalam menghadapi masalah yang sulit. Studi Mirnet (Tuakli dkk, 1990) juga menambahkan bahwa dari survei terhadap para perokok, dilaporkan bahwa orang tua dan saudara yang merokok, rasa bosan, stres dan kecemasan, perilaku teman sebaya merupakan faktor yang menyebabkan keterlanjutan perilaku merokok pada remaja. Jika dilihat data-data mengenai keterlibatan remaja dalam berbagai perilaku negatif, maka kita akan menemukan angkaangka yang mengejutkan dan mengkhawatirkan. Kelompok Smoking and Health memperkirakan sekitar enam ribu remaja mencoba rokok pertamanya setiap hari dan tiga ribu di antaranya menjadi perokok rutin (Stop, 2000).

Perilaku merokok pada remaja umumnya semakin lama akan semakin meningkat sesuai dengan tahap perkembangannya yang ditandai dengan meningkatnya frekuensi dan intensitas merokok, dan sering mengakibatkan mereka mengalami ketergantungan nikotin (Laventhal dan Cleary dalam Mc Gee, 2005). Efek dari merokok hanya meredakan kecemasan selama efek dari nikotin masih ada, malah ketergantungan nikotin dapat membuat seseorang menjadi tambah stres (Parrot, 2004). Indri Kemala Nasution : Perilaku Merokok Pada Remaja, 2007 USU Repository 2008 


\section{Bahaya Merokok}

Terpapar asap rokok selama 8 jam sebanding dengan merokok langsung sebanyak 20 batang perhari. Konsekuensi dari merokok antara lain meningkatnya kejadian infeksi saluran nafas bagian atas, batuk, asma, sinusitis, penyakit kardiovaskular, kanker, mengganggu fertilitas, lahir kurang bulan, kematian maupun absen dari kerja atau sekolah. Anak atau kaum muda yang merokok, pertumbuha dan perkembangan parunya segera akan terpengaruh oleh asap rokok tersebut.

Efek dari rokok atau tembakau memberi stimulasi depresi ringan, gangguan daya tangkap, alam perasaan, alam pikiran, tingkah laku dan fungsi psikomotor. Jika dibandingkan zat-zat adiktif lainnya rokok sangatlah rendah pengaruhnya, maka ketergantungan kepada rokok tidak begitu dianggap gawat (Roan, 1979:33).

Perokok pasif dapat meningkatkan resiko penyakit kanker, paru-paru dan jantung koroner. Lebih dari itu menghisap asap rokok orang lain dapat memperburuk kondisi pengidap penyakit: angina, asma dan alergi akibat asap rokok.

\section{Minuman Keras}

Minuman Keras adalah semacam minuman yang berbahaya dan membahayakan bagi orang yang meminumnya. Dalam sebuah hadist Nabi Muhammad SAWmelaknat khamr atau minuman keras yang memabukkan mencakup kepada sepuluh golongan : (1) yang memerasnya; (2) yang minta diperaskan; (3) yang meminumnya; (4) yang membawanya: (4) yang minta di antarkan; (5) yang menuangkannya; (6) yang menjualnya; (6) yang makan hasil penjualannya; (7) yang membelinya; (8) yang minta dibelikan"

Demikian salah satu hadist riwaayat At Tirmidzi dan Ibnu Majah. Al Khamr secara bahasa atinya tertutup, yang diambil dari kosa kata khimar yang berarti kerudung (penutup kepala) dan kata khamr yang berarti minuman yang memabukkan atau minuman keras (miras). Demikianlah orang yang mengkonsumsi khamr menyebabkan akalnya tertutup sehingga tidak bisa mengingat dirinya atau mabuk. Rasulullah SAW menetapkan khamr (miras) tidak semata dari bahan untuk membuat khamr (miras), tetapi lebih dari pengaruh yang ditimbulkan, yaitu memabukkan.

Miras (minuman keras), apapun nama yang digunakan oleh manusia tetapi dapat membuat yang mengonsumsinya mabuk hilang akal, seperti ganja, arak, tuak dan sejenisnya, hukumnya adalah haram. Khamr didefenisikan oleh Raslullah SAW adalah sesuatu yang memabukkan yang dapat mengakibatkan hilngnya akal. Padahal akal adalah organ mulia anugerah Allah Subhanahu wa Ta'ala untuk mengontrol gerak gerik anggota tubuh. Maka hukum Islam menegaskan meminum khamr baik sedikit apalagi banyak hukumnya adalah haram. Rasulullah SAW bersabda: "Minuman apapun kalau banyaknya itu memabukkan. Maka sedikitnyapun adalah haram." (HR. Ahmad, Abu Daud, dan At Tirmidzi).

\section{E. Narkoba}

dari narkoba adalah $\begin{array}{r}\text { singkatan } \\ \text { berbahaya. }\end{array}$ Seperti ungkapan 'api kecil adalah kawan dan jika menjadi besar adalah lawan'. Ini ungkapan yang sangat pas untuk menggambarkan tentang narkoba.

Dalam dunia medis, narkoba bisa menjadi obat-obat yang berkhasiat untuk penyembuhan. Penggunaan narkoba dalam dunia medis adalah legal. Nah yang menjadi penyalahgunaan adalah ketika seseorang yang mengkonsumsi narkoba tanpa adanya pengawasan dari seorang ahli kesehatan atau dokter. Bila seseorang menggunakan narkoba tanpa adanya pengawasan dari dokter akan sangat membahayakan si pengguna karena umumnya narkoba mengandung zat-zat beracun yang bisa menyebabkan pengguna narkoba akan selalu ketergantungan atau kecanduan terhadap obat-obatan tersebut, merusak organorgan tubuh, mempengaruhi berkurangnya daya pikir seseorang atau membuat pikiran menjadi tidak rasional dan kerusakan otak secara permanen. Akibat yang lebih mengerikan lagi adalah berujung pada kematian.

Dilihat dari segi penggunaannya, narkoba dibedakan menjadi 2 golongan. Yakni pengguna narkoba 'jalanan' (ilegal) dan penggunaan narkoba legal dalam dunia medis yang disalahgunakan. Dari penggolongan jenisnya, narkoba di bedakan menjadi 3 
golongan besar yakni narkotika, psikotropika dan zat aditif lainnya. Ketiga jenis narkoba tersbut juga sering disebut dengan napza.

Data dan fakta menunjukkan persentase tertinggi penguna narkoba adalah anak-anak sekolah dan anak-anak remaja. Sedangkan lokasi tempat mereka 'menikmati' barang haram tersebut umumnya di kos-kosan, clubclub malam, diskotik dsbnya. Mereka dijadikan sasaran empuk oleh para pengedar untuk mengeruk keuntungan dari penjualan barang haram tersebut. Tidak pada mereka saja, kalau kita menonton berita di tv banyak contoh kasus artis-artis yang terlibat dengan penggunaan narkoba. Bahkan ada yang tertangkap sampai 2 kali dalam kasus yang sama. Ini menunjukkan cengkeraman narkoba yang sangat hebat pada seseorang sehingga sulit untuk melepaskannya.

Mengingat maraknya peredaran narkoba di Indonesia yang sepertinya hukum di Indonesia tidak membuat mereka (para pengedar atau bandar ) jera, selalu saja ada penyeledupan narkoba ke wilayah Indonesia. Ini menjadi tugas dan kewajiban kita sebagai orang tua untuk mengawasi dan lebih mewaspadai anak-anak kita di dalam pergaulan. Awasi tingkah laku dan pola hidup anak-anak. Orangtua harus peka terhadap perubahan sikap anak-anak yang memang kalau mereka terlibat penggunaan narkoba akan terlihat dengan sangat jelas. Kita patut dan wajib menjaga dan melindungi mereka dari serangan hal semacam itu. Begitu mereka terjerumus, adalah masalah besar di kemudian hari.

Namun bagaimana dengan kita yang tidak mengerti atau awam terhadap hal itu? Nah berikut di bawah ini ada buklet-buklet dalam bentuk file PDFyang dapat didownload secara gratis yang sangat berguna untuk kita mengetahui dan mengenali jenis-jenis narkoba, efek samping penggunaan narkoba baik jangka pendek maupun jangka panjang serta kesaksian-kesaksian para pengguna narkoba.

\section{F. Bahaya Narkoba Bagi Remaja atau Pelajar}

Penyalahgunaan narkotika dan obatobatan terlarang di kalangan generasi muda dewasa ini kian meningkat Maraknya penyimpangan perilaku generasi muda tersebut, dapat membahayakan keberlangsungan hidup bangsa ini di kemudian hari. Karena pemuda sebagai generasi yang diharapkan menjadi penerus bangsa, semakin hari semakin rapuh digerogoti zat-zat adiktif penghancur syaraf. Sehingga pemuda tersebut tidak dapat berpikir jernih. Akibatnya, generasi harapan bangsa yang tangguh dan cerdas hanya akan tinggal kenangan.Sasaran dari penyebaran narkoba ini adalah kaum muda atau remaja. Kalau dirataratakan, usia sasaran narkoba ini adalah usia pelajar, yaitu berkisar umur 11 sampai 24 tahun. Hal tersebut mengindikasikan bahwa bahaya narkoba sewaktu-waktu dapat mengincar anak didik kita kapan saja.

\section{G. Tujuan Kegiatan}

Mengacu pada permasalahan yang diajukan, maka tujuan penyuluhan program pengabdian pada masyrakat antara lain :

1. Meningkatkan pemahaman terhadap siswa-siswi tingkat sekolah dasar mengenai kemungkinan ancaman bahaya merokok, minuman keras dan bahaya narkoba di Kecamaran Campaka, Kabupaten Purwakarta.

2. Menumbuhkan kewaspadaan siswasiswi sekolah dasar mengenai tantangan, hambatan dan gangguan terhadap bahaya merokok, minuman keras dan bahaya narkoba di Kecamatan Campaka Kabupaten Purwakarta.

Meningkatkan kemampuan untuk menangkal terhadap ancamanan, tantangan, hambatan dan gangguan bahaya merokok, minuman keras dan bahaya narkoba pada siswa-siswi sekolah dasar di Kecamatan Campaka, Kabupaten Purwakarta.

\section{H. Khayalak Sasaran}

Khalayak sasaran yang ditetapkan, bahwa sejak dini siswa-siswi SD dan SMP menjadi target utama untuk menangkal adanya ancaman, tantangan, hambatan, dan gangguan terhadap merokok, minuman keras, dan bahaya narkoba, sehingga diharapkan adanya penyuluhan ini semua ancaman, hambatan, tantangan dan gangguan terhadap merokon, minuman keras dan bahaya narkoba dapat dicegah. Minimal di lingkungan sekolah dan 
keluarga peserta penyuluhan di Kecamatan Campaka Kabupaten Purwakarta, Jawa Barat.

\section{METODE KEGIATAN}

Metode yang digunakan dalam pemberian penyuluhan adalah ceramah dengan pendekatan kasus yang sering terjadi di daerah perkotaan. Selain itu, menunjukkan beberapa kasus krusial dengan memaparkan gambar berupa foto-foto kasus. Harapannya dengan menunjukkan gambar foto tersebut, minimal memberikan efek tidak melakukan hal-hal negatif seperti dalam foto tersebut. Metode lain dengan bermain peran dan pertukaran pikiran dan tanya jawab, agar peserta penyuluhan dapat menyelami kejadian-kejadian yang terjadi di masyarakat.

\section{A. Agenda Kegiatan}

Kegiatan penyuluhan ini dilakukan selama 2 hari dengan perincian 1 hari di tingkat SD dan 1 hari di tingkat SMP atau setara dengan masing-masing sekolah 4 (empat) jam pelajaran efektif, tetapi jika kegiatan ini dalam waktu yang telah ditentukan belum tuntas dalam arti materi dan pemecahan masalahnya belum selesai, maka dilanjutkan pada hari di luar jam pelajaran.

\section{HASIL KEGIATAN PENYULUHAN}

Penyuluhan pada tingkat ini dilaksanakan di SDN 1 Campaka pada tanggal 15 Agustus 2015, pukul 09.00-13.00 WIB. Penyuluhan bertempat di Ruang kelas V-a dan V-b SDN 1 Campaka.

Penyuluhan pada tingkat ini penulis laksanakan di SMPN 1 Campaka pada tanggal 22 Agustus 2015, pukul 09.00-13.00 WIB, yang bertempat di Ruang Laboratorium SMPN 1 Campaka.

Kegiatan penyuluhan yang telah dilaksanakan di Desa Campaka, baik di SDN 1 Campaka, maupun di SMPN 1 Campaka ini tidak lepas dari beberapa kekurangan yang menjadi hambatan terkait proses kegiatan penyuluhan yang efektif dan maksimal. Pada penyuluhan di tingkat $\mathrm{SD}$, terdapat kurang adanya koordinasi dengan pihak sekolah mengenai fasilitas speaker dan microphone. Selain itu, guru-guru sekolah yang semula akan turut hadir dalam kegiatan penyuluhan nampak hadir tidak sampai kegiatan penyuluhan itu selesai. Beda halnya dengan di SMP, para peserta cenderung pasif dan tidak peduli dengan pemaparan dari penyuluhan ini.

\section{A. Hasil Kegiatan}

Dengan adanya kegiatan penyuluhan

akan bahaya merokok, minuman keras, dan narkoba bisa mencerdaskan dan memotivasi siswa-siswi, baik di tingkat SD maupun SMP bahwa ketiga aspek itu sangat berbahaya bagi mereka, baik fisik maupun non-fisik, baik skala saat ini mupun masa yang akan datang. Bahkan dengan adanya penyuluhan ini, tingkat perokok di bawah umur (tingkat SD dan SMP), bisa ditekan dan bahkan terus mengalami progress yang positif, yang mana tingkat perokok di tingkat SD dan SMP terus mengalami peningkatan, dan semakin berani untuk merokok di tempat umum.

Dari hasil pengamatan selama mengikuti penyuluhan, bahwa banyak siswa yang kurang mengetahui jenis-jenis minuman keras dan jenis-jenis narkoba. Dengan metode yang diterapkan pada penyuluhan ini, diantaranya metode pemaparan kasus yang sering terjadi di masyarakat dan dengan pemutaran video dan gambar-gambar termasuk jenis minuman keras dan narkoba diperkenalkan kepada peserta penyuluhan. Setelah diperkenalkan jenis-jenis minuman keras dan narkoba banyak dari mereka yang bertanya tentang bahaya minuman keras dan narkoba tersebut.

Berdasarkan pemaparan penyaji, maka sebagian besar mereka peserta yang mengikuti penyuluhan tersebut dapat memahami jenisjenis minuman keras dan narkoba serta bahaya yang mengancam dan mengintai pada siswasiswi di tingkat SD dan SMP tersebut diharapkan dapat dihindari dengan memahami bahaya tersebut. Ke depan, dari hasil 
penyuluhan tersebut, diharapkan juga bahwa para orang tua siswa=siswi tingkat SD dan SMP harus memahami tentang hal ini, dengan maksud untuk mencegah kemungkinankemungkinan terjadi di lingkungan mereka. Hal ini mendapat sambutan dari pihak kepala desa setempat agar pelaksanaan tersebut dapat direalisasikan.

Pemaparan materi diselingi dengan diskusi kelompok kecil dari peserta penyuluhan yang hasilnya diluar dugaan penyelenggara, yaitu bahwa pemaparan presentasi hasil diskusi mereka, menemukan titik temu antara peserta penyuluhan dengan penyelenggara terutama pada tingkat SMP. Titik temu yang dimaksudkan adalah presentasi hasil diskusi dari peserta memaparkan kasus-kasus yang berkenaan dengan penyalahgunaan minuman keras dan bahaya narkoba yang pada tahun terakhir ini banyak terjadi di kalangan remaja yang ada di Kabupaten Purwakarta, sehingga mereka sangat memahami faktor penyebab dan akibat yang ditimbulkan ketika barang haram terebut masuk di kalangan mereka. Hal ini merupakan suatu kemajuan tingkat pengetahuan peserta penyuluhan yang secara langsung maupun tidak langsung mengenai kalangan mereka, sehingga harapan dari penyelenggara penyuluhan diharapkan cepat tercapai untuk menghadapi ancaman, ganguan, tantangan dan hambatan dari masuknya minuman keras dan narkoba di kalangan mereka.

\section{B. Hasil Pembahasan}

Dalam pelaksanaan penyuluhan selama dua hari tersebut, berjalan sesuai dengan jadwal yang telah direncanakan sebelumnya. Akan tetapi, tidak terlepas adanya pihak-pihak yang merupakan faktor pendukung dan juga pihakpihak yang merupakan faktor penghambat, antara lain seperti di bawah ini :

\section{Faktor Pendukung}

Faktor pendukung penyuluhan bahaya merokok, minuman keras, dan narkoba di tingkat SD dan SMP :
- Antusiasme siswa/i, baik di tingkat SD dan SMP yang sangat bersahabat dan terbuka dengan kegiatan program yang dilakukan.

- Peserta penyuluhan yang banyak, bahkan memadatkan ruangan tempat penyuluhan. Hal ini membuktikan, bahwa peserta penyuluhan merasa perlu untuk mengetahui materi yang disajikan dalam penyuluhan tersebut. Dari tiga puluh peserta dari SD kelas tinggi ( kelas 4, 5, dan 6) serta dari SMP kelas 8 dan 9, seluruhan dapat mengikuti penyuluhan ini sesuai jadwal yang direncanakan. Khususnya peserta dari SMP tersebut, ketika dilakukan diskusi dengan pendekatan model penyajian gambar-gambar kasus yang dipaparkan oleh penyuluh, banyak dari mereka yang menanggapi dan memberikan pertanyaan, sehingga suasana dalam ruangan kelas menjadi lebih hidup.

- Pihak sekolah yang mau memfasilitasi dalam kegiatan penyuluhan, sehinggan kegiatan berjalan dengan komunikatif. Berdasarkan pengamatan ketika dilaksanakan penyuluhan ini, pihak kepala sekolah sebelumnya dilakukan pendekatan untuk mendapatkan persetujuan ketika hendak dilaksanakan penyuluhan tersebut. Hal ini dapat dibuktikan perijinan untuk penggunaan ruang kelas dan waktu yang dijadwalkan dapat diterima. Tetapi, pihak sekolah menyayangkan bahwa pelaksanakan penyuluhan ini hanya satu hari untuk tingkat SMP dan satu hari untuk tingkat $\mathrm{SD}$, sehingga menurut pihak sekolah kurang waktunya.

\section{Faktor Penghambat}

Faktor penghambat penyuluhan bahaya merokok, minuman keras, dan narkoba di tingkat SD dan SMP : 
- Pihak sekolah yang kurang mau berperan aktif dalam kegiatan penyuluhan, seperti hadir dalam kegiatan penyuluhan, memberikan masukan kepada penyelenggara, atau dengan menghadirkan para guru dan orang tua siswa untuk berpartisipasi atas pelaksanaan program ini. Meskipun demikian, hasil yang dicapai dalam pelaksanaan penyuluhan dapat dikatakan berhasil.

- Siswa/i yang cenderung gaduh dan membuat kebisingan yang melebihi ambang batas membuat kami sulit menciptakan suasana yang kondusif. Terutama pada tingkat SD, ketika pelaksanaan diskusi atau tanya jawab setelah pemaparan dari penyelenggara banyak peserta yang kurang fokus dalam mengikuti program ini. Tetapi syukur alhamdulilah, berkat metoda atau cara untuk melerai situasi tersebut dapat dikendalikan dengan cara melakukan pendekatan kuis-kuis dengan diberikan hadiah bagi yang dapat menjawab pertanyaan dari penyuluh, sehingga suasana yang tadinya gaduh dapat dikendalikan dengan cara tersebut.

\section{KESIMPULAN}

Berdasarkan pengamatan dan pelaksanaan penyuluhan ini, dapat disimpulkan bahwa :

Pelaksanaan penyuluhan mendapatkan respon positif bagi peserta penyuluhan. Hal ini terbukti antusiasme peserta penyuluhan bersemangat mengikuti agenda pemaparan dari penyaji.

Disamping itu, dari orang tua peserta mengharapkan ada langkah selanjutnya setelah dilakukan penyuluhan ini, sehingga tidak putus dipertengahan jalan terutama dari pemerintah setempat untuk saling mengawasi tentang tingkat laku siswa-siswa terhadap ancaman, tantangan hambatan dan gangguan merokok minuman keras dan bahaya narkoba di lingkungan masyarakat dan keluarga.

\section{DAFTAR PUSTAKA}

Aditama, Tjandra Yoga. 2001. Masalah Rokok dan Penggulangannya. YP IDI

Ahsan, Abdillah. 2006. "Warta Demografi”, Profil Perokok dan Pengendalian Rokok di Indonesia, Tahun 36 No 3 2006

Arikunto. 2006. Prosedur Penelitian Suatu Pendekatan Praktek Edisi Revisi V. Jakarta: Rineka Cipta.

Budiarto, Eko. 2001. Biostatistika untuk kedokteran dan kesehatan masyarakat. Jakarta : EGC

Evania, Putri. 2011. Menguak Rahasia Otak Perempuan. Yogyakarta : Sinar Kejora

Gunawan, Arif. 2011. Remaja dan permasalahannya.

Yogyakarta: Hanggar Kreator

Hidayat, A. Aziz Alimul. 2003. Riset Keperawatan dan Teknik Penulisan Ilmiah. Jakarta : Salemba Medika

Hidayat, A. Aziz Alimul. 2008.Riset Keperawatan dan Teknik Penulisan Ilmiah.Jakarta : Salemba Medika

Hurlock, Elizabeth B. 2004. Psikologis Perkembangan. Jakarta : Erlangga.

Istiqomah, Umi. 2003. Upaya Menuju Generasi Tanpa Merokok. Jakarta: CV. Seti-Aji

Mu'tadin, Zainun. 2002. "Remaja dan Rokok".(www.e-psikologi.com) diakses tanggal 7 Maret 2011

$\begin{array}{ccr}\text { Nursalam. 2003. Konsep } & \text { dan } & \text { Penerapan } \\ \text { Metodologi } & \text { Penelitian } & \text { Ilmu } \\ \text { Keperawatan. } & \text { Jakarta } & \text { Salemba } \\ \text { Medika. } & & \end{array}$

Notoatmodjo, Soekidjo. 2005. Metodologi Penelitian Kesehatan Edisi Revisi. Jakarta :Rineka Cipta.

Notoatmodjo, Soekidjo. 2010. Metodologi penelitian kesehatan. Jakarta : Rineka Cipta. 
P-ISSN : 0216-7484 E-ISSN : 2597-8926

DOI : doi.org/10.21009/sarwahita.121.07

Poltekkes, Depkes. 2010. Kesehatan Remaja, Satiti, A. 2009. Strategi Rahasia Berhenti problem dan solusinya. Jakarta: Merokok. Yogyakarta: Datamedia Salemba Medika. 